\title{
Malaysian Real Estate Investment Trusts: A Performance and Comparative Analysis
}

\author{
Tze San Ong (Corresponding author) \\ Department of Accounting and Finance \\ Faculty of Economics and Management, University Putra Malaysia, Malaysia \\ Tel: 60-3-8946-7571Ｅ-mail: tzesan@econ.upm.edu.my \\ Boon Heng Teh, Chin Hooi Soh \& Yat Liang Yan \\ Faculty of Management, Multimedia University Malaysia \\ Accepted: March 19, 2012 \\ Published: May 1, 2012 \\ URL: http://dx.doi.org/10.5539/ijef.v4n5p73
}

Received: February 29, 2012

doi:10.5539/ijef.v4n5p73

\begin{abstract}
This study examines the investment performance of conventional and Islamic Real Estate Investment Trusts (REITs) listed in Malaysia over the 2005-10 time period. Analysis reveals that both conventional and Islamic REITs experienced negative monthly return during 2008 global financial crisis (GFC) period, and positive monthly return post GFC period. Compared to market indices, most REITs are under-performed before GFC. Divergent findings were reported during the GFC and post-GFC, depending on the measurement tools used. Based on Treynor and Sharpe measurements, most REITs under-performed the market portfolio in during and post GFC period. However, according to Jensen measurement, the REITs out-performed market indices during and post GFC period. Despite these seemingly divergent findings, this study can assist investors, regulatory body, fund managers and academics to make a better informed investment decision on Malaysia REITs. This study has provided interesting and important information and insights into the performance of Malaysia REITs.
\end{abstract}

Keywords: REITs, Performance measurements, Global financial crisis, Malaysia

\section{Background of the Study}

The source of income generation for Real Estate Investment Trusts (REITs) comes from the rental of commercial real-estate. Commercial properties are basically cyclical income-producing assets with inflation-hedging attributes that appear to provide long-term asset appreciation. Hence, REITs are deemed to be defensive stocks, consist of cyclical income-producing assets, though having some potential of asset appreciation (Graff, 2000). Do Malaysia Real Estate Investment Trusts (REITs) generate value for shareholders? How do investments in Malaysia REITs performed in comparison with market indices? How did Islamic REITs performed in comparison to conventional REITs? How was the performance of Malaysia REITs before, during, and after a financial crisis? The growing popularity of REITs investments makes these questions pertinent, and a study on the emerging market such as Malaysia would also prove beneficial for a globally diversified portfolio investor in terms of market timing and country selection.

REITs are not new to the world. In fact, REITs started in the United States in 1960 (Graff, 2001), In many other developed countries, REITs have been developed over decades and with steady fixed income, provides an alternative to fixed deposit investments. REITs Investors are typically long-term investors with moderate risk such as insurance companies, pension funds, unit trust funds and individual investors. As many investors may not be able to invest in a huge property portfolio, REITs gain strength from pool of funds gathered and invest into high profile and high value properties for better return. Table 1.1 shows the number of REITs in global market.

REIT investment in developing countries like Malaysia is proclaimed to be very attractive as the value of real estate in developing nations lags behind developed nations (JP, 2012). Table 1.1 indicates that a total of 97 REITS investments were listed in Asia (Ernst and Young, 2010). This study aims to study Malaysia REITs because it offers a competitive business environment (World Economic Forum, 2009) and was not as severely affected by the global financial crisis as most other Asian markets (Newell and Razali, 2009), as well as Malaysia being one of the most transparent property markets in Asia, only exceeded by Hong Kong and Singapore (Jones, 2008). 


\subsection{The development of Real Estate Investment Trust (REITs) in Malaysia}

Amongst Asian countries, Malaysia was the earliest to publicly list property trust (Newell, Ting and Acheampong, 2002). The Central Bank of Malaysia, also known as Bank Negara approved the regulatory framework for Malaysia listed property trust in 1986 (Hamzah and Rozali, 2006); and developed specific Securities Commission guidelines for listed property trust funds in 1991, revising it further in 1995. In 1986, Malaysia started the property trust market, known as Property Trust Funds (PTFs), the predecessor of REITs (Newell, Ting and Acheampong, 2002). Since then, it has progressed to become a well-established REIT market in Malaysia, with fourteen REITs listed as of year 2010 (Security Commission of Malaysia, 2010).

In August 2006, Malaysia became the world's first developer of Islamic Real Estate Investment Trust, which is compliant with the principle of Shariah. The introduction of Islamic REITs was facilitated by guidelines issued by the Malaysia Securities Commission. These guidelines provided a new global benchmark for development of Islamic REITs, enhancing the important role of Malaysia to promote the growth and development of Islamic market in the International Financial Community. As an ethical investment vehicle, Islamic REITS were embraced by global Muslim investors (Ibrahim and Ong, 2008). By year 2010, Malaysia has established four Islamic REITs which are Al-Aqar KPJ REIT listed on Aug 2006, Al-Hadharah Boustead REIT listed on Feb 2007 and Axis REIT listed on Aug 2005. Axis REIT was converted to Islamic REIT in December 2008. Summary of REITs stock quote and listed on main board of Bursa Malaysia Securities Berhad is shown in Table 2.2.

REITs have been proven to be a popular and successful investment vehicle in the United States and Australia (Hamzah and Rozali, 2010). However, such does not seems to be the case in Malaysia. Investors seem to perceive Malaysia REITs unfavorably (Ong, et al., 2011). There seems to be a lack of awareness of REITs amongst Malaysian demand, and a correspondingly lower demand. Consequentially, the participation rates of Malaysian investors on REITs are much lower than in other countries (Newell and Osmandi, 2009). Furthermore, the market capitalization of Malaysian real-estate lags behind many countries; even countries in Asia (refer to Figure 1.1). In addition to all these, Malaysia REITs have performed poorly since their inception in 1980s till year 2004 (Newell, Ting and Acheampong, 2002; Ting, 1999). This study seeks to provide answers to the performance of REITs and whether Islamic REITs performs better than conventional REITs.

\subsection{Research Objective}

The research objectives of this paper are:

1. To examine the performance of Malaysian REITs before, during and after the 2008 Global Financial Crisis

2. To investigate whether conventional real estate investment trust provides higher return than market benchmark, Kuala Lumpur Composite Index (KLCI).

3. To investigate whether Islamic real estate investment trust provides higher return than market benchmark, Emas Shariah Index.

4. To compare the performance of Malaysian Islamic REITs against the conventional REITs.

\section{Previous Researches on REITs Performance}

There have been limited empirical studies on the performance analysis of REITs and its predecessor, listed property trust in Malaysia. Kok and Khoo (1995) examined the performance of three listed property trusts, namely Amanah Harta Tanah PNB, First Malaysia Property Trust and Arab Malaysian First Property Trust for the period 1991 to 1995 by using Treynor, Sharpe and Jensen Index measurements. The results indicated listed property trusts are generally out-performed than market during bear markets, but performed poorly during bull markets.

Newell, Ting and Acheampong (2002) examined for the period March 1991 to March 2000 the performance of four listed property trusts in Malaysia, namely Maybank Property Trust Fund One, Amanah Harta Tanah PNB, First Malaysia Property Trust and Arab Malaysian First Property Trust. Annual returns are used to measure as returns in this study, standard deviation as proxy to risks and coefficient of variations as risk-adjusted performances. Kuala Lumpur Composite Index (KLCI), Kuala Lumpur Office Property Index (KLOPI), and Kuala Lumpur Properties Index (KLPI) are proxy to market index. The annual return of Amanah Harta Tanah PNB is higher than market return. whereas the standard deviation of Maybank Property Trust Fund One, Amanah Harta Tanah PNB, and First Malaysia Property Trust are higher than market risk. The coefficients of variation of each of the listed property trusts are under-performed the KLCI.

Abdullah and Wan Zahari (2008) investigated the performance of Malaysian listed property companies in the pre-crises, during and post-crisis period using Adjusted Sharpe Index, Sharpe Index, Treynor Index, Adjusted Jensen Index and Jensen Index. The Kuala Lumpur Property Index (KLPI) and Kuala Lumpur Composite Index (KLCI) 
were used as market benchmarks. Their results showed that the listed property companies significantly out-performed the market portfolio.

There is very limited research and literate have been studying regarding the Islamic REIT. Osmadi (2006) is specifically study the development of Islamic REITs. Ibrahim and Ong (2008) investigate the performance of operational Islamic-compliant REITs for both restricted and non-restricted scheme. The non-compliant REITs outperform complaint REITs for equally-weighted portfolio. However, the findings are inconsistent with the study of Alhenawi and Hassan (2011) examine the relative performance REITs for both restricted and non-restricted scheme. The results show that compliant REITs have out-performed non-compliant REITs and provide less volatile investment vehicle. Moreover, compliant REITs can gain more return for equally-weighted portfolio and reduce loss for value-weighted portfolio during financial crisis period.

Newell and Osmadi (2009) assessed the risk-adjusted performance, significance, and portfolio diversification benefit of Islamic and conventional REITs in Malaysia over the period of 2006 to 2008. The findings indicate that Islamic REITs provide portfolio diversification benefit and low risk level features compared to conventional REITs. Ong, et al. (2011) investigated the development and performance of Malaysia REITs by using Net Value approach (NAV). Malaysian REITs generally traded at a premium to NAV. Malaysian REITs are much better companies for transparency, disclosure, share liquidity, depth of management and corporate democracy.

This paper attempts to expand the existing research to investigate the performance of conventional REITs and Islamic REITs for the period 2005 to 2010. Unlike previous studies that tended to use only one measurement index (e.g., Kim et al., 2002), this study employs a comprehensive set of performance measurements such as Treynor Index, Sharpe Index and Jensen Alpha Index. Using a comprehensive set of measurements such as Treynor Index, Sharpe Index and Jensen Alpha Index could enhance the validity of the results.

\section{Data Collection Method}

For this study, the data were collected from multiple resources such as Bank Negara Malaysia, Securities Commission, and DataStream. The four types of data used in this study are the FBM KLCI, FBM Emas Shariah Index, individual REITs price and 3-month Treasury bill rate (TBR). The monthly returns of KLCI and Emas Shariah Index serves as proxy for market benchmark. The market portfolio of REITs refers to all assets in the market. Three month treasury bills rates have been gathered from Bank Negara Malaysia used as the risk-free rate in this study. The data for conventional REITs were taken from August 2005 to December 2010, while the data for Islamic REITs will take from their inception in August 2006 until December 2010. The period of study will cover the full period introduction of all the REITs. The performance analysis of Malaysia REITs was divided into three sub periods to compare the performance before, during and after global financial crisis 2008.

\subsection{Sample Size}

The Total population of Malaysia REITs consists of 14 publicly listed companies and all of them are included in this study (such as Al-Aqar KPJ, Al-Hadharah Boustead, AmFirst, Amanah Harta Tanah PNB, Amanahraya, Atrium, Axis, CapitaMall Malaysia Trust, Hektar, Quil Capita Trust, Starhill, Sunway, Tower, and UOA). In this study, the individual REIT prices were collected based on the closing price of all 14 listed companies in the last day of the each month.

\section{Performance Measurement Methodology}

The performance all REITs are measured by using three different performance measurement model included Sharpe, Treynor, and Jensen Alpha Index.

\subsection{Sharpe Index}

Sharpe is a useful measurement of performance that excess return which actual return minus risk free rate return divided by standard deviation.

$$
\text { Sharpe Ratio }=\quad \frac{R_{r}-R_{f}}{\sigma_{r}}
$$

Where:

$R_{r}=$ the observed average return on REIT

$R_{f}=$ the average return on 3 months Malaysian Treasury Bills

$\sigma_{r}=$ The standard deviation returns for REIT 


\subsection{Treynor Index}

Treynor is another measurement of performance that excess return which actual return minus risk free rate return divided by beta.

$$
\text { Treynor Ratio }=\quad \frac{R_{r}-R_{f}}{\beta_{r}}
$$

Where:

$R_{r}=$ the observed average return on REIT

$R_{f}=$ the average return on 3 months Malaysian Treasury Bills

$\beta_{r}=$ The systematic risk of REIT relative to the market portfolio

The risk free rate will be represented as the Three months Malaysian Treasury Bills whereas beta $(\beta)$ will represent systematic risk.

\subsection{Jensen Alpha Index}

The third measurement of performance is Jensen Alpha which determines the average return of asset portfolio predicted by Capital Asset Portfolio Model (CAPM), given market return $\left(R_{M}\right)$ and beta $\left(\beta_{p}\right)$.

$$
\text { Jensen Ratio }=\alpha_{p}=R_{r}-\left[R_{f}+\beta_{p}\left(R_{M}-R_{f}\right)\right]
$$

Where:

$\alpha_{p}=$ the Jensen's Alpha on REIT

$R_{r}=$ the average return on REIT

$R_{f}=$ the average return on 3 months Malaysian Treasury Bills

$\beta_{r}=$ The systematic risk of REIT relative to the market portfolio

\section{Malaysian REITs Performance Analysis}

\subsection{Malaysian REIT Performance Analysis for Entire Period}

Table 5.1 presents the returns, risk and performance measures for the conventional REITs and Islamic REITs, over the period of study. The data suggests that Sunway gained the highest return $(2.38 \%)$ by achieving lowest total risk $(2.546 \%)$ and systematic risk $(0.072 \%)$ as compared to market portfolio. By using the Sharpe and Jensen measurements, Sunway under-performed the market portfolio by -0.1841 and -0.0042 respectively. In terms of market capitalization, asset size, free float and average daily turnover volume, Sunway could be deemed as the largest Malaysia REIT. The benefits from the reputation and recognition of the Sunway brand name could provide support to Sunway REIT as a sound investment portfolio to investors.

The data in Table 5.1 also suggests that CapitaMalls Malaysia Trust was the second optimum investment portfolio for investors; it generated the second highest monthly return (1.55\%) with lower total risk (3.825\%) and systematic risk $(0.419 \%)$. CapitaMalls Malaysia Trust experienced the highest value with Treynor, Sharpe and Jensen performance measurements as compared to the market portfolio. CapitaMalls Malaysia Trust was the only one really out-performed the market portfolio based on Jensen measure, with the positive values of 0.001 . CapitaMalls Malaysia Trust is the largest Shopping Mall REIT in Malaysia and has the second highest market capitalization. The consistent attractive yield could have entice the support of investors to CaptialMalls Malaysia Trust.

However, the findings also reveal that Quill Capita Trust experienced negative return of $-0.25 \%$. Quill Capita Trust purchased assets during the Singapore financial downturn, resulting in Malaysia Quill Capita Trust experiencing losses. Meanwhile, Starhill also experienced the negative return of $-0.26 \%$ which was slightly lower than Quill Capita Trust. The explanation for negative value could be due to Starhill ownership of a large number of undeveloped land.

Table 5.1 also exhibits the Islamic REITs performance measurements throughout the full study period. The results indicate that the average return for all Islamic REITs under-performed the market portfolio. The explanation to this result could be Islamic REITs in Malaysia are not well recognized by many investors as the only three Islamic REITs were listed on Bursa Malaysia. It can be consider as new type of investment. The comprising Shariah principle of Islamic REITs might lead to misunderstandings that Islamic REITs are meant for Muslim investors. Furthermore, the small numbers of Islamic REITs does not seem able to create sufficient buzz and interest of domestic and foreign investors. 
Overall, the results reveal that Sunway and CapitalMalls Malaysia Trust were the most profitable conventional REIT relative to the market portfolio. Sunway and CapitalMall Malaysia Trust were listed after the global financial crisis. This fortuitous timing could result in investors' positive expectation of future growth prospects. Most conventional REITs under-performed the market portfolio and provided lower average monthly return and higher total risk than market portfolio. On the other hand, most of the conventional REITs have lower systematic risk than market portfolio. Based on the analysis of Treynor, Sharpe, and Jensen index, the results shows that all conventional REITs provide negative values, indicating the poor performances of overall conventional REITs.

\subsection{Malaysian REITs Performance Analysis Pre-Global Financial Crisis}

Table 5.2 presents the returns, risk and performance measures for the conventional REITs from August 2005 to August 2007 and Islamic REITs from August 2006 to August 2007, before GFC period. The results indicate that the ranges of the average monthly return of all the REITs were very volatile. All REITs recorded positive average return, except for Starhill, which experienced negative return of $-0.01 \%$. A plausible reason for Starhill REIT's lackluster performance could be the perception of low dividends associated with the REIT.

The results indicate that Hektar generated the superior average return of 5.26\%; it significantly over-performed the respective market return. A possible reason could be that Hektar successfully received investment from Frasers Centerpoint Trust, which secured Hektar with a total investment of $31.06 \%$. Hektar was able to improve its performance to provide good returns to its investors. Further analysis using Sharpe, Treynor and Jensen measurements also indicate that Hektar greatly out-performed the market portfolio.

The results also reported that Tower and Quil Capita Trust experienced the attractive return relative to the market portfolio, respectively, 2.69 and 2.63 percent respectively. Further analysis with the Treynor, Sharpe, and Jensen measures reveals that both of these REITs also out-performed the market portfolio.

Table 5.2 also contains the Islamic REITs performance analysis before GFC period. Both Al-Aqar KPJ and Al-Hadharah Boustead under-performed the market in terms of average monthly return. A possible explanation for this result is that the Islamic REITs were established only two years prior to GFC, hence, it may not have generated sufficient goodwill and confidence to investors. Furthermore, Islamic REITs being new to the market then would have less uptake in the market. In addition, both these Islamic REITs had higher total risk than the market portfolio. Investors are unfamiliar with REITs will probably avoid taking additional risk premium.

Overall, all REITs offered volatile returns at a higher level of total risk compared to market portfolio. The analysis of monthly standard deviation shows that most conventional REITs provided higher risk or at most, slightly lower than market portfolio risk. Both CapitaMalls Malaysia Trust and Sunway REITs were not listed before the GFC; therefore they were not being analyzed for the pre-crisis period.

The results show that Hektar was the only conventional REITs generating positive value, which shows superior performance against the market portfolio based on Sharpe, Treynor and Jensen measurements. All of the Islamic REITs under-performed the market portfolio by providing lower return against the market portfolio with higher risks. The results show that the performances of all REITs generated negative value. The results indicate that the poor performances of all REITs except Hektar for the pre-GFC period under the Treynor, Sharpe, and Jensen measurements.

\subsection{Malaysian REITs Performance Analysis during Global Financial Crisis}

Table 5.3 presents the returns, risk and performance measures for the conventional REITs and Islamic REITs from September 2007 to September 2008 during GFC period. The data suggests that majority of REITs reported the worst monthly average return and at higher level of risk performance except for Amanah Harta Tanah PNB and AmanahRaya. With the exception of these two REITs, all the other REITs as well as the market index, recorded negative returns during GFC period. Malaysia was badly affected by GFC. Investors tend to not invest during crisis period due to the lack of confidence in investments.

Amanah Harta Tanah PNB and AmanahRaya were able to generate positive return during GFC period, with $0.29 \%$ and $0.02 \%$ respectively. Further analysis of Treynor, Sharpe, and Jensen measurements shows that Amanah Harta Tanah PNB generated the highest value during GFC period. A plausible reason is that the establishment of Amanah Harta Tanah PNB was the first REITs to obtain the sponsor from Malaysian Government in year 2007. This could improve the performance of AmanahRaya. The Treynor and Jenson analysis also indicates that AmanahRaya out-performed the market portfolio.

The results also reveal that although Al-Aqar KPJ and Al-Hadharah Boustead generated negative monthly return, they managed to out-performed the market portfolio. Based on Treynor, Sharpe, and Jensen measurements, 
Al-Hadharah Boustead also out-performed the market portfolio. However, Axis experienced worst monthly return than market return.

Overall, all REITs offered negative monthly return except Amanah Harta Tanah PNB and AmanahRaya and mostly accompanied by higher level of risk compared to market portfolio. Two conventional REITs (Amanah Harta Tanah PNB and AmanahRaya) were able to generate positive monthly return during GFC period. Both CapitaMalls Malaysia Trust and Sunway are not analyzed during the crisis period as they were only listed after the global financial crisis. In summary, the results show that all REITs provided inferior performances during GFC period using the Treynor, Sharpe, and Jensen measurements.

\subsection{Malaysian REITs Performance Analysis Post Global Financial Crisis}

Table 5.4 presents the returns, risk and performance measures for the conventional REITs and Islamic REITs from October 2008 to December 2010 for post GFC period. The data suggest that all REITs reported positive monthly average return for post GFC period. Part of the explanation is that Asian REITs started to recover from the global financial crisis.

Sunway experienced the highest monthly average return (2.38\%) with the lowest total risk $(2.54 \%)$ and systematic risk $(0.072 \%)$ as compared to the market portfolio. Further analysis shows that Sunway out-performed the market portfolio by using the Sharpe and Jensen measurements, -0.1841 and -0.0042 respectively. It can be argued that Sunway REIT is the largest REIT in Malaysia. The diversified portfolio of Sunway REIT encompasses real estate in hospitality, retail, and commerce sectors which gives significant benefit above pure-play REITs. The diverse of properties will benefit from diverse sources of income for both international and domestic investors. It can be said that Sunway was the most profitable conventional REIT with the highest return and lowest risk. Therefore, it is able to attract both international and domestic investors to invest in Sunway REITs.

The data also recorded that the second profitable conventional REIT obtained by CapitaMalls Malaysia Trust, which generated monthly average return $(1.55 \%)$, and average total risk $(3.825 \%)$. CapitaMalls Malaysia Trust experienced the highest value as compared to the market portfolio by using Treynor, Sharpe and Jensen performance measurements. Furthermore, the Jensen measurement indicates that CapitaMalls Malaysia Trust was the only REIT really out-performed the market portfolio with a positive value (0.0010).

The data also shows that Axis experienced with highest average monthly return (1.42\%) but this was achieved by entailing the highest level of risk $(8.302 \%)$ as against the market portfolio. meanwhile, Axis out-performed the market portfolio with both Treynor and Sharpe measurements, -0.0394 and -0.11 respectively. A plausible reason for this is Axis' acquisition of new properties and increasing of rental incomes.

Overall, the results suggest that Sunway and CapitaMalls Malaysia Trust were the best-performing real estate investments, providing high returns at lower level of risk for post GFC period, followed by Amanah Harta Tanah PNB, UOA and Atrium. Overall, the values of performance measurements for REITs showed improvement after GFC. Furthermore, increasing number of REITs out-performed the market portfolio based on Jensen measures. According to Global REIT report 2010, REITs signifies the initial recovery of the property market from global financial crisis. Around the world, REIT markets provided positive rates return in the year of 2009.

\section{Conclusion}

This study investigates the risk and return performance of Malaysian REITs relative to market portfolio. Do Malaysian REITs generate value for shareholders? How do investments in Malaysia REITs performed in comparison with market indices? How did Islamic REITs performed in comparison to conventional REITs? How was the performance of Malaysia REITs before, during, and after a financial crisis?

The stock and property market of Malaysia like elsewhere was badly affected during 2008 Global Financial Crises. The GFC was a result of the United States of America experiencing a financial crisis that was triggered by substantial defaults on subprime mortgage in 2008 .

Malaysian REITs naturally experienced negative returns during this difficult period. The findings were also consistent with research results of Liow and Sim (2006), who reported that almost all Asian real estate markets provided negative returns over the period of 1997-2000. Similar result was reported by. Kallberg et al. (2002), who recorded real estate return volatility during the crisis period. The results were supported by Liow and Adair's (2008) study, which concluded that Asian real estate companies reported inferior average monthly returns and experienced higher risk compared to Asian stocks.

Like their Asian counterparts, Malaysian REITs made substantial recovery post-GFC with positive monthly returns. Nevertheless, based on Treynor and Sharpe measurements, most Malaysian REITs under-performed the market 
portfolio in pre, during, post GFC period. The Jensen measurement shows that REITs under-performed the market portfolio in the pre GFC but out-performed in during and post GFC period. The finding differs from Hamzah and Rozali's (2010) study that reported REITs experienced poorer performance in pre and post crisis period but generated better performance during the crisis based on adjusted Sharpe, Treynor and Adjusted Jensen Alpha. The results of this study also differs from Kok and Khoo's (1995) earlier study which concluded that listed property trusts are generally out-performed the market portfolio during bear market period and under-performed during bullish market period.

In general, the results also suggest that the higher level of risk experienced by majority of REITs may be due to the short time frame since the establishment of REITs creating concern among investors who are thinking about adding a property investment to their portfolio. Risk-adverse investors normally will not consider taking additional risk with unprofitable investments. The result is consistent with the study by Liow and Adair (2008). They found that all of the real estate market except for New Zealand, Australia, and US experienced higher risks that respective market index. Risk adverse investors and individual investor that knows nothing about investment will sell their REITs especially during financial crisis. As a conclusion, REITs cannot offer diversification benefits to investors when included in a share portfolio.

The above results show the inferior performance in REITs in the pre and during GFC period, based on the Treynor and Sharpe measurements. The findings also show significant improvement of REITs performance, based on the Jensen measurement. The results can be supported by the prior study by Newell (2003) who reported almost all the real estate markets were abruptly affected by Asian financial crisis 1997. The findings of Newell (2003) indicate that almost all the real estate consequently generated inferior performance than market index during downturn period. However, most of the real estate recovered from crisis period and presents significant improved risk-adjusted performance after downturn period.

\subsection{Limitations and Recommendations}

The limitation of this study is a relatively shorter period of study for Malaysian REITs, as conventional REITs and Islamic REITs only started listing on Bursa Malaysia in August 2005 and August 2006 respectively. Furthermore, there is only four Islamic REITs listed on Bursa Malaysia. The short period of study with only 14 REITs might not a reliable for performance of Malaysia REITs in a long term period. Two REITs, namely CapitaMall Malaysia Trust and Sunway were not giving the empirical information before and during the global financial crisis period, as they were listed only in 2010.

Future research can be expanded to include another measure of performance such as Net Asset Value (Ong et al. 2011) to enhance the validity of the results. In addition, further research should concentrate on the performance analysis of Malaysian REITs for both local and international perspective to advice investors on whether they want to invest in locally or internationally. An exploratory study can be undertaken to better comprehend the performance of Malaysian REITs. The data can be collected through observation and interviews to examine the perception and attitudes of local and global investors towards Malaysian REITs. As the increasing number of REITs, the future research can give significant development and growth of real estate market in Malaysia.

\section{References}

Abdullah, N. A. H., \& Wan Zahari, W. M. (2008). Performance of Property Listed Companies in Malaysia: 1996-2007. Unpublished Master thesis, University Utara Malaysia, Malaysia.

Alhenawi Y., \& Hassan M. K. (2011). The Relative Performance of Debt-restricted Real Estate Investment Trusts (REITs): Does Faith Matter?. Unpublised manuscript, University of New Orleans New Orleans, LA.

EPRA. (2010). Global REIT Survey, EPRA.

Ernst and Young. (2010). Global REIT Report 2010.

Graff, R. A. (2001). Economic Analysis suggests that REIT investment characteristics are not as advertised, Journal of Real Estate Portfolio Management, 7(2), 99-124.

Hamzah, A. H., \& Rozali, M. B. (2010). Empirical Investigation on the Performance of the Malaysian Real Estate Investment Trusts in Pre Crisis, During Crisis and Post Crisis Period. International Journal of Economics and Finance, 2(2), 62-69

Ibrahim, M. F., \& Ong, S. E. (2008). Shariah Compliance in Real Estate Investment. Journal of Real Estate Portfolio Management, 14(4), 401-414.

Jensen, M. C. (1968). The Performance of Mutual Funds in the period 1945-1964. Journal of Finance, 23(2), 389-416. http://dx.doi.org/10.2307/2325404 
Jones L. L. (2008). Real Estate Transparency Index, JLL. [online] Available: http://www.joneslanglasalle.com/pages/grati_home.aspx (March 14,2012)

JP (2011). REITs in Malaysia - A new asset class of investment option, http://www.estate123.com/reviews_articles/article_review_detail.aspx?a_id=7 (28 ${ }^{\text {th }}$ Feb 2012).

Kim, H. J., Mattila, A. S., \& Gu Z. (2002). Performance of hotel real estate investment trusts: a comparative analysis of Jensen indexes. International Journal of Hospitality Management, 21, 85-97.http://dx.doi.org/10.1016/S0278-4319(01)00026-3

Kok, K. K., \& Khoo, K. L. (1995). Performance of Property Trusts in the Kuala Lumpur Stock Exchange. Capital Markets Review, 3, 1-19.

Liow, K. H., \& Adair, A. (2009). Do Asian real estate companies add value to investment portfolio? Journal of Property Investment and Finance, 27(1), 42-64. http://dx.doi.org/10.1108/14635780910926667

Liow, K., \& Sim, M. C. (2006). The risk and return profile of Asian property markets. Pacific-Rim Property Research Journal, 12(3), 283-310.

Newell, G., \& Osmadi, A. (2009). The development and Preliminary performance analysis of Islamic REITs in Malaysia. Journal of Property Research, 26(4), 329-347.http://dx.doi.org/10.1080/09599916.2009.485417

Newell, G., Ting, H. K., \& Acheampong, P. (2002). Listed Property Trusts in Malaysia. Journal of Real Estate Literature, 10, 109-118.

Ong, T. S., Teh, B. H., \& Chong, M. P. (2011). A Study On The Performance Of Malaysian Real Estate Investment Trusts From 2005-2010 By Using Net Asset Value Approach. International Journal of Economics and Research, 2(1), 1-15.

Osmadi, A. (2006). A guide to Islamic finance and Islamic REITs. Australian Property Journal, 212-218.

Securities Commission of Malaysia. (2010). Listed of Listed Real Estate Investment Trust, SCM.

Sharpe, W. F. (1966). Mutual Fund Performance. Journal of Business, 39 (1), 119-138. http://dx.doi.org/10.1086/294846

Ting, K. H. (1999). Listed Property Trusts in Malaysia: A Comparative Performance Analysis. Paper Presented at International Real Estate Society Conference, Kuala Lumpur, Malaysia. January 1999.

Treynor, J. (1965). How to Rate Management of Mutual Funds. Harvard Business Review, 8, 63-75.

World Economic Forum. (2009). Global Competitiveness Report 2009-10, WEF. 
Table 1. Number of REITs by country

\begin{tabular}{|c|c|c|c|}
\hline Country & 2010 & 2009 & 2008 \\
\hline \multicolumn{4}{|l|}{ Asia } \\
\hline Hong Kong & 7 & 7 & 7 \\
\hline Japan & 37 & 41 & 41 \\
\hline Malaysia & 14 & 13 & 13 \\
\hline Singapore & 20 & 20 & 20 \\
\hline South Korea & 5 & 3 & 6 \\
\hline Taiwan & 8 & 8 & 8 \\
\hline Thailand & 6 & 6 & 6 \\
\hline Total REITs in Asia & 97 & 98 & 101 \\
\hline \multicolumn{4}{|l|}{ North America } \\
\hline Canada & 32 & 30 & 33 \\
\hline US & 172 & 142 & 171 \\
\hline Total REITs in Americas & 204 & 172 & 204 \\
\hline \multicolumn{4}{|l|}{ Europe } \\
\hline$\overline{\text { Belgium }}$ & 14 & 15 & 14 \\
\hline Bulgaria & 19 & 19 & 19 \\
\hline France & 45 & 44 & 47 \\
\hline Germany & 2 & 4 & 2 \\
\hline Greece & 2 & 2 & 2 \\
\hline Italy & 1 & 1 & 1 \\
\hline Netherlands & 8 & 6 & 8 \\
\hline Turkey & 13 & 13 & 13 \\
\hline UK & 19 & 20 & 18 \\
\hline Total REITs in Europe & 123 & 124 & 124 \\
\hline \multicolumn{4}{|l|}{ Australasia } \\
\hline Australia & 60 & 57 & 67 \\
\hline New Zealand & 8 & 8 & 8 \\
\hline Total REITs in Oceania & 68 & 65 & 75 \\
\hline \multicolumn{4}{|l|}{ Middle East \& Africa } \\
\hline South Africa & 5 & 5 & 5 \\
\hline Total REITs in Middle East \& Africa & 5 & 5 & 5 \\
\hline TOTAL GLOBAL REITS & 497 & 464 & 509 \\
\hline
\end{tabular}

Sources: Compilation from Ernst and Young (2010), Macquarie Equities Research (2009)

Table 2. Summary of REITs Stock Quote and Listed on Main Board of Bursa Malaysia Securities Berhad

\begin{tabular}{llll}
\hline REITs & Stock Quote & Date Listed & Types of Property \\
\hline $\begin{array}{l}\text { Conventional REITs } \\
\text { 1. AmFirst }\end{array}$ & AMFIRST & 21 December 2006 & Office \\
2. Amanah Harta Tanah PNB * & AHP & 25 March 1997 & Office \\
3. Amanahraya & ARREIT & 26 February 2007 & hotel \\
4. Atrium & ATRIUM & 2 April 2007, industrial, \\
5. CapitaMalls Malaysia Trust & CMMT & 16 July 2010 & Industrial \\
6. Hektar & HEKTAR & 4 December 2006 & \\
7. Quil Capita Trust & QCAPITA & 8 January 2007 & Retail \\
8. Starhill & STAREIT & 16 December 2005 & Office \\
9. Sunway & SUNREIT & 8 July 2010 & Hotel, retail, apartment \\
10. Tower & TWREIT & 12 April 2006 & \\
11. UOA & UOAREIT & 30 December 2005 & Office \\
Islamic REITs. & & & Office, retail \\
12. Al-Aqar KPJ & ALAQAR & 10 August 2006 & Healthcare \\
13. Al-Hadharah Boustead & BSDREIT & 8 February 2007 & Palm oil plantations \\
14. Axis ** & AXREIT & 3 August 2005 & Office, industrial \\
\hline
\end{tabular}

Source: Ong, et al., 2011; Newell and Osmadi, 2009

*Established as Property Trust Funds (PTFs), being converted to REITs since August 2005

** being reclassified as Islamic REITs since December 2008 
Table 3. Performance analysis for Malaysia REITs: Aug 2005-Dec 2010 and Islamic REITs Aug 2006-Dec 2010

\begin{tabular}{|c|c|c|c|c|c|c|}
\hline & $\begin{array}{c}\text { Avg. } \\
\text { Return (\%) }\end{array}$ & $\begin{array}{c}\text { Avg. } \\
\text { Risk (\%) }\end{array}$ & Beta & Treynor & Sharpe & Jensen \\
\hline \multicolumn{7}{|l|}{ Conventional REITs } \\
\hline Amanah Harta Tanah PNB & 1.1100 & 5.7930 & 0.5190 & -0.0447 & -0.4001 & -0.0127 \\
\hline Amanahraya & 0.1800 & 4.4500 & 0.1390 & -0.1930 & -0.6030 & -0.0238 \\
\hline AmFirst & 0.6300 & 3.3440 & 0.3200 & -0.0678 & -0.6486 & -0.0151 \\
\hline Atrium & 0.2000 & 6.4500 & 0.3360 & -0.0761 & -0.3966 & -0.0180 \\
\hline CapitaMalls Malaysia Trust & 1.5500 & 3.8250 & 0.4190 & -0.0042 & -0.0461 & 0.0010 \\
\hline Hektar & 0.7000 & 7.5200 & 0.3590 & -0.0587 & -0.2804 & -0.0137 \\
\hline Quil Capita Trust & -0.2500 & 8.3980 & 0.7460 & -0.0407 & -0.3620 & -0.0140 \\
\hline Starhill & -0.2600 & 3.6360 & 0.4390 & -0.0719 & -0.8683 & -0.0230 \\
\hline Sunway & 2.3800 & 2.5460 & 0.0720 & -0.0651 & -0.1841 & -0.0042 \\
\hline Tower & 0.5400 & 6.1540 & 0.6440 & -0.0365 & -0.3820 & -0.0108 \\
\hline UOA & 0.5500 & 5.2760 & 0.3460 & -0.0677 & -0.4442 & -0.0167 \\
\hline$K L C I$ & 0.8700 & 4.1880 & 0.4420 & -0.0455 & -0.4802 & -0.0112 \\
\hline \multicolumn{7}{|l|}{ Islamic REITs } \\
\hline Al-Aqar KPJ & 0.4500 & 4.4486 & 0.2180 & -0.1099 & -0.5387 & -0.0190 \\
\hline Al-Hadharah Boustead & 0.6100 & 4.8970 & 0.3760 & -0.0575 & -0.4413 & -0.0135 \\
\hline Axis & 0.8000 & 6.9840 & 0.2870 & -0.0720 & -0.2960 & -0.0170 \\
\hline Emas Shariah Index & 0.9660 & 5.0952 & 0.2950 & -0.0630 & -0.3648 & -0.0131 \\
\hline
\end{tabular}

Notes: Avg. Return = Average Monthly Return, Avg. Risk = Average Monthly Standard deviation

Table 4. Performance analysis for Malaysia REITs: Aug 2005-Aug 2007

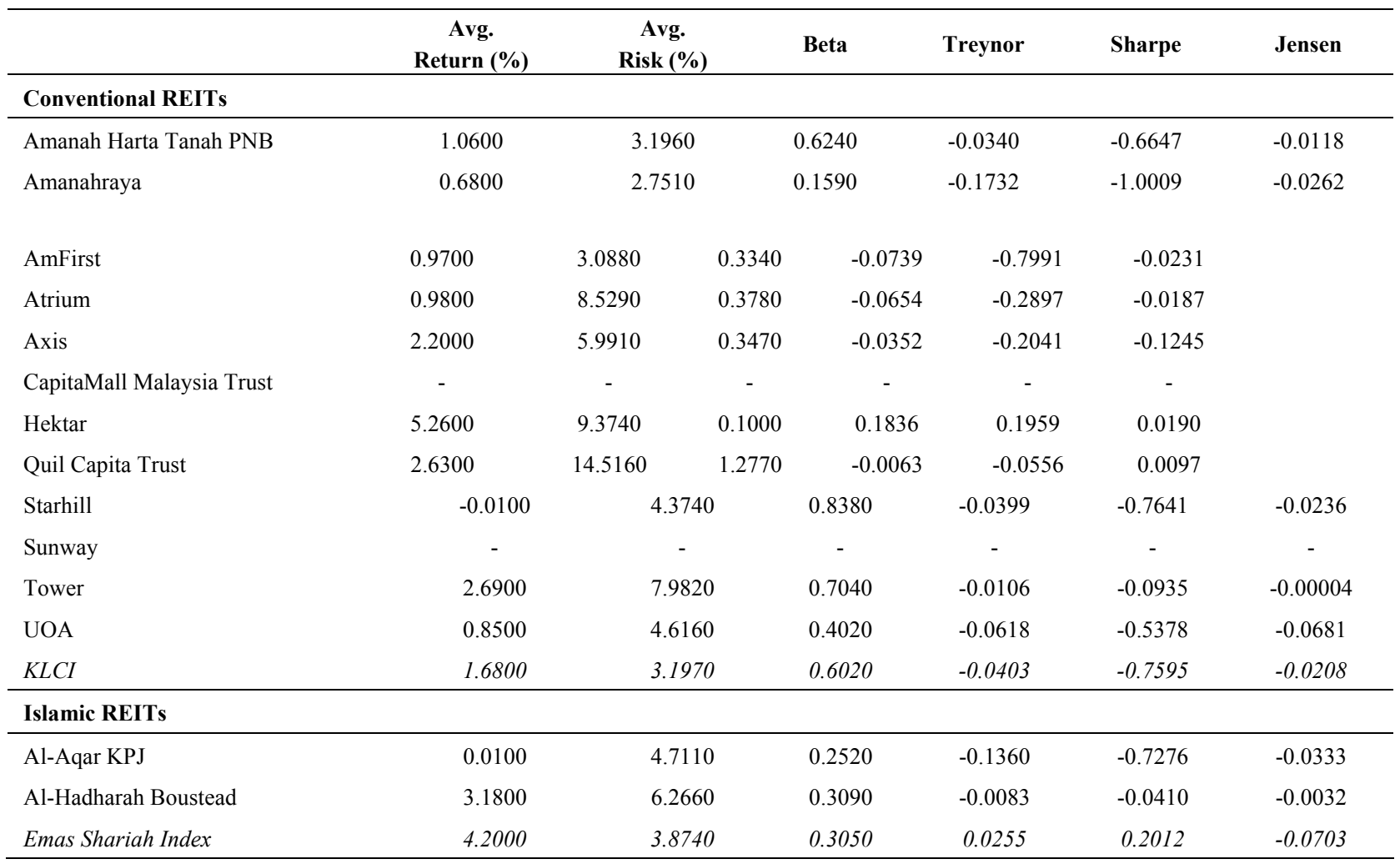

Notes: Avg. Return = Average Monthly Return, Avg. Risk = Average Monthly Standard deviation 
Table 5. Performance analysis for Malaysia REITs: Sept 2007-Sept 2008

\begin{tabular}{|c|c|c|c|c|c|c|}
\hline & $\begin{array}{c}\text { Avg. } \\
\text { Return (\%) } \\
\end{array}$ & $\begin{array}{c}\text { Avg. } \\
\text { Risk (\%) } \\
\end{array}$ & Beta & Treynor & Sharpe & Jensen \\
\hline \multicolumn{7}{|l|}{ Conventional REITs } \\
\hline Amanah Harta Tanah PNB & 0.2900 & 4.2330 & 0.4470 & -0.0702 & -0.7414 & -0.0097 \\
\hline Amanahraya & 0.0200 & 2.3160 & 0.3130 & -0.1086 & -1.4681 & -0.0188 \\
\hline AmFirst & -0.6600 & 1.8900 & 0.2150 & -0.1816 & -2.0657 & -0.0286 \\
\hline Atrium & -2.2100 & 4.0110 & 0.3590 & -0.1568 & -1.4037 & -0.0389 \\
\hline CapitaMalls Malaysia Trust & - & - & - & - & - & - \\
\hline Hektar & -2.6200 & 6.6410 & 0.5360 & -0.1127 & -0.9097 & -0.0344 \\
\hline Quil Capita Trust & -3.0600 & 10.2160 & 0.4910 & -0.1320 & -0.6343 & -0.0410 \\
\hline Starhill & -1.5200 & 2.2260 & 0.1320 & -0.3468 & -2.0565 & -0.0430 \\
\hline Sunway & - & - & - & - & - & - \\
\hline Tower & -1.6300 & 4.6980 & 0.6540 & -0.0772 & -1.0749 & -0.0188 \\
\hline UOA & -1.7600 & 5.2840 & 0.1450 & -0.3577 & -0.9817 & -0.0993 \\
\hline$K L C I$ & -1.4300 & 4.0000 & 0.3780 & -0.1283 & -1.2126 & -0.0625 \\
\hline \multicolumn{7}{|l|}{ Islamic REITs } \\
\hline Al-Aqar KPJ & -0.4200 & 2.1640 & 0.1970 & -0.1950 & -1.7753 & -0.0287 \\
\hline Al-Hadharah Boustead & -0.6900 & 4.9290 & 0.3960 & -0.1039 & -0.8351 & -0.0216 \\
\hline Axis & -1.8800 & 3.9180 & 0.2510 & -0.2115 & -1.3551 & -0.0719 \\
\hline Emas Shariah Index & -1.5300 & 4.8510 & 0.2820 & -0.1756 & -1.0209 & -0.0503 \\
\hline
\end{tabular}

Notes: Avg. Return = Average Monthly Return, Avg. Risk = Average Monthly Standard deviation

Table 6. Performance analysis for Malaysia REITs: Oct 2008-Dec 2010

\begin{tabular}{|c|c|c|c|c|c|c|}
\hline & $\begin{array}{c}\text { Avg. } \\
\text { Return (\%) }\end{array}$ & $\begin{array}{c}\text { Avg. } \\
\text { Risk (\%) }\end{array}$ & Beta & Treynor & Sharpe & Jensen \\
\hline \multicolumn{7}{|l|}{ Conventional REITs } \\
\hline Amanah Harta Tanah PNB & 1.5400 & 7.9510 & 0.4990 & -0.0421 & -0.2643 & -0.0155 \\
\hline Amanahraya & 0.1600 & 5.4260 & 0.0310 & -0.7501 & -0.4285 & -0.0229 \\
\hline AmFirst & 1.0800 & 3.8950 & 0.3810 & -0.0330 & -0.3225 & -0.0083 \\
\hline Atrium & 1.2500 & 6.9900 & 0.2830 & -0.0386 & -0.1561 & -0.0078 \\
\hline CapitaMalls Malaysia Trust & 1.5500 & 3.8250 & 0.4190 & -0.0042 & -0.0461 & 0.0010 \\
\hline Hektar & 0.9500 & 6.8000 & 0.3160 & -0.0438 & -0.2036 & -0.0103 \\
\hline Quil Capita Trust & 0.4600 & 5.1980 & 0.4960 & -0.0379 & -0.3616 & -0.0133 \\
\hline Starhill & 0.1700 & 3.5970 & 0.3630 & -0.0597 & -0.6027 & -0.0177 \\
\hline Sunway & 2.3800 & 2.5460 & 0.0720 & -0.0651 & -0.1841 & -0.0042 \\
\hline Tower & 0.4000 & 5.3970 & 0.5560 & -0.0349 & -0.3599 & -0.0133 \\
\hline$K L C I$ & 1.2300 & 4.7920 & 0.3690 & -0.0301 & -0.2315 & -0.0305 \\
\hline \multicolumn{7}{|l|}{ Islamic REITs } \\
\hline Al-Aqar KPJ & 1.0600 & 5.2110 & 0.1860 & -0.0688 & -0.2457 & -0.0105 \\
\hline Al-Hadharah Boustead & 0.7700 & 4.6030 & 0.3810 & -0.0413 & -0.3416 & -0.0110 \\
\hline Axis & 1.4200 & 8.3020 & 0.2320 & -0.0394 & -0.1100 & -0.0377 \\
\hline Emas Shariah Index & 1.0900 & 5.0700 & 0.2690 & -0.0464 & -0.2462 & -0.0247 \\
\hline
\end{tabular}

Notes: Avg. Return = Average Monthly Return, Avg. Risk = Average Monthly Standard deviation 


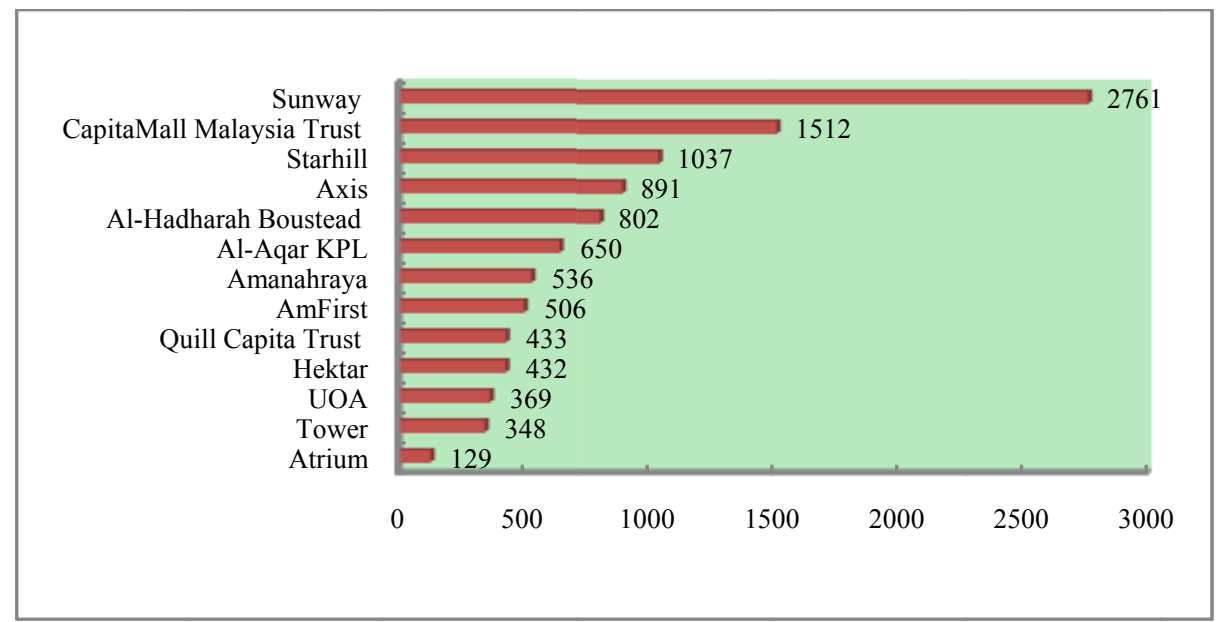

Figure 1. Market Capitalization in RM million as at 31 December 2010 